\title{
editorial
}

\section{Revolutionary social work: promoting sustainable justice}

\author{
Masoud Kamali, masokama68@gmail.com \\ Independent scholar, Sweden
}

Jessica H. Jönsson, jessica-hanna.jonsson@oru.se Örebro University, Sweden

To cite this article: Kamali, M. and Jönsson, J.H. (2019) Editorial: revolutionary social work: promoting sustainable justice, Critical and Radical Social Work, vol 7, no 3, 293-314, DOI: 10.1332/204986019X15688881109268

\section{Introduction}

This special issue, 'Revolutionary social work', is based on our long-standing interest and engagement in critical and radical social work research, education and praxis, which we share with many of our colleagues around the globe. It concerns a common struggle against an unsustainable neoliberal and post-colonial world order that has resulted in increasing inequalities, conflicts and social and ecological problems. This special issue includes contributions by critical and radical scholars who believe that another world, in which promoting social justice and human dignity is the first priority of social work practices, is possible. Although this is an academic piece of work, it is not limited to academic circles. The aim of this special issue is to encourage readers engaged in social work practices to include a radicalism for social change in their everyday activities. Against this backdrop, this introduction now aims to theoretically explore the necessity of a revolutionary reorientation of social work research, education and praxis, and to suggest some strategic revolutionary actions.

\section{Revolutionary social work: struggling against global inequalities and oppressions}

The decades following the 1970s - and the political victory of the champions of neoliberalism, Ronald Reagan in the US and Margaret Thatcher in UK - have witnessed an aggressive neoliberal globalisation. This neoliberal world order is defended by very powerful governments and actors who can, whenever they want, make use of military force and other oppressive forms of action to eliminate any opposition. As Rosa Luxemburg, by correcting Marx's Eurocentric perspective, already in 1913 argued, Western capitalist states' military machinery enables and facilitates their global imperialist expansions (Luxemburg, 2003). 
Increasing socio-economic inequalities and social problems related to wars, conflicts, forced migration and political instabilities are among the consequences of the uncontrolled global domination of neoliberalism (Kamali, 2015; Ferguson et al, 2018). Several years of marketisation and securitisation policies in countries around the globe show that the capitalist neoliberal system does not tolerate deviances from, or even efforts at the reform of, what is its market fundamentalism. The recent neoliberal transformations of the welfare states in Nordic countries, as well as the increasing securitisation of social policies and social work are clear illustrations of this (Kamali and Jönsson, 2018; Finch et al, 2019). This means that revolutionary mobilisations and actions, within and beyond the (democratic and non-democratic) systems that are legitimising neoliberal globalisation and oppressions, are necessary.

Among the enduring changes enacted during the last four decades have been: the liberalisation of the financial markets, fundamentally reducing state control over the market; the privatisation of all commercial state properties; major tax reforms in the market - and in the rich's favour; the substantial reduction of welfare services to the needy; the privatisation of a compulsory education system; and establishing New Public Management in public sector organisations and institutions. Such substantial changes have not only been committed by neoliberal and right-wing parties, but have also been accepted and even enacted by social-democratic parties (Motta and Bailey, 2007). The neoliberal capitalist system is not capable of solving challenging socio-economic, political and ecological problems, and humanity needs an alternative system beyond the marketisation of every aspect of human existence (Baer, 2012).

This all-encompassing neoliberal globalisation can be considered a 'passive revolution' - a notion deployed by Gramsci to account for the ideological process by which capitalism, and the ideal type of Adam Smith's free market, has become the only valid system, presented as if 'there is no alternative' (to borrow Thatcher's infamous expression). Such a troubled world is governmentalised and constitutes the 'end of history'. If Fredrich Hegel considered a capitalist system led by a constitutional monarchy as the goal of human history, Fukuyama (1992) sees the capitalist liberaldemocratic system as the final political organisation of human history. Despite the (unearned) merits ascribed to liberal democracy, the modern development of democracy and the capitalist system is complex and has included many non-liberal and non-democratic developments, such as Nazism and fascism (Kamali, 2006). From the 19th-century liberal-constitutionalist movements to the post-Napoleonic restoration (1815-48), and to the restorations following the social upheaval of the First World War that led to the rise of fascism, Americanism and Fordism (Morton, 2007), modern history is indicative of the 'passive revolution' by which a world capitalist system has been established.

The concept of a 'passive revolution' encompasses structural transformations of the global economy, and the emergence of new social, political and cultural formations, in a fashion that has never happened before in human history. By the concept of a 'passive revolution', Gramsci (1971) means that the world has been modernised and developed in the same way as the Piedmontese state in Italy modernised and unified the Italian peninsula. In contrast to the revolutionary change in France and the glory of the French Revolution (circa 1789), the Italian state replaced revolutionary masses and took the lead in the unification and modernisation of Italy in a process of 'passive revolution'. This is not to say that there has historically been a lack of revolutionary movements that have been brutally cracked down upon by the state 
or foreign capitalist powers; indeed, such events have occurred in many countries, such as Germany, Mexico, Chile, Iran, Turkey and Cuba. Rather, it is to emphasise the complex and non-revolutionary ways by which capitalism and its current structures of neoliberalism have been globally established as uncontested models of human existence. The concept of a 'passive revolution' can help to explain the continuous reforms within the system of capitalism (Sassoon, 1987; Morton, 2007; Bruff, 2010), particularly when it is combined with Gramsci's (1971) concept of 'hegemony', by which the very system of neoliberal-capitalist-inspired transformations is culturally legitimised (see also Garrett, 2008).

However, it should be said that the 'passive revolution' of neoliberalism could not have taken place without coercive means - that is, the direct exercise of power on the one side and, on the other, the fostering of a 'superstructure', or the cultural and political acceptance of neoliberal capitalism as 'the only alternative' for structuring human societies. The globalisation of neoliberalism has entailed wars, violence and conflicts by which oppositions to neoliberal marketisation and imperialism have been brutally crushed. The use of the military and police forces against protestors against marketisation have taken place as a result of close alliances between major Western powers and their corrupted satellite regimes in non-Western countries. Neoliberal capitalist powers, such as the US and the European Union (EU), have utilised their economic and military powers to force many governments and nations to follow the rules of the neoliberal 'game'. Contenders are subjected to economic sanctions and when such sanctions do not work, military force, as well as the threat of the use of such force, has frequently been deployed, for instance, in Iraq, Afghanistan, Venezuela and Iran. These neoliberal wars and interventions depart from previous interventions by calling on the military to undertake post-conflict reconstruction in accordance with neoliberal ideology and policies (Schwartz, 2011).

The Cold War could not have been won by capitalist regimes using only 'soft' economic and political means; it entailed bloody proxy wars in non-Western countries, which destroyed the infrastructures of many countries and caused millions of people to lose their lives, while yet millions more were injured and displaced as the results of coups d'état and dictatorship in Western-supported satellite states. Ethnic and religious conflicts were nurtured and supported, and the military were intrinsically involved in the overthrow of many 'undesired' political systems and regimes - conducted in order to pursue and monitor the globalisation of neoliberalism. This is why it is not completely correct to call global neoliberalisation a 'passive revolution'. It may have been 'passive' in Western countries, but it absolutely was violent for many of the non-Western countries going through 'multiple modernities' projects (Kamali, 2006, 2012).

\section{The neoliberal 'legitimate' hegemony}

Antonio Gramsci has stressed the role of hegemony for the reproduction of the capitalist system and its coercive power and functions. As Nicola Short (2007) elaborates, although the means of coercion are held by socially dominant groups and the state, the legitimacy of its use must be constructed across society. The role of hegemony is to create a 'common sense' by which the existing capitalist order is accepted as 'natural' by those subjected to it. The state consolidates the capitalist system through a network of institutions and cultural practices that create acceptance among 
people. This results in a process by which most acts of dissent can be incorporated within the system, while those that cannot be accommodated become marginalised as 'unfeasible' (Bassett, 2008). The exercise of force and violence underlies hegemony; however, the stronger the acceptance and 'naturalisation' of the system of order, the less the need for exercising violence (while the weaker the acceptance, the greater the need). (Hobsbawm 1977: 209) outlined Gramsci's original theoretical contributions, stressing his view that 'a ruling class relies not only on coercive power and authority but on consent deriving from hegemony - what Gramsci calls "the intellectual and moral leadership"'. Such intellectual and moral leadership defines which actions are acceptable and permitted, and which are not. This means that the hegemonic leadership defines the limits within which we can struggle, the field of 'common sense' or 'popular consciousness' (Grossberg, 1996: 162).

The same argument is presented by Bourdieu (1988) and Foucault (2003), who each stress that the socio-economic and political order is reproduced by both physical and symbolic means. Here, Bourdieu (1988: 14) means that the legitimation of the social order is a result of the use of systems and techniques that provide people with 'structures of perception and appreciation' that make them accept the social order as self-evident. People internalise these particular forms of perception and appreciation, which are also reproduced by the exercise of symbolic violence - a coercive system of reward and punishment. Those who accept the social order and help in reproducing it are rewarded (in different ways), while those opposing it or violating it will be punished. This can be illustrated within the organisation of social work, where social workers who adjust themselves to neoliberal routines are rewarded and those protesting are punished (Jönsson, 2019a). People learn through their experiences how to adjust themselves to the social order and to accept it as legitimate. The more people employ accepted thoughts and actions and find them useful for themselves and become their carriers, the more they adjust themselves to the system - and, in turn, the more the social order becomes an inseparable part of their habitus and identity. Bourdieu sees the state as the most important organ for exercising violence, not only in the Weberian sense of it having a monopoly over the means of exercising physical violence, but also in it having the monopoly over the means of exercising symbolic violence. As Cummins (this volume) argues (while outlining the theoretical approach of Stuart Hall), understanding the mechanism of the cultural hegemony of capitalist Western countries is more important for discerning the reproduction of the current world order than is focusing on its merely economic aspects.

Foucault (2007) explains the legitimation of the neoliberal social order as a result of governmentalisation. The term refers to the techniques of government or governing (gouverner) and to modes of thought (mentalité). In this, he means that understanding the exercise of power by the modern state cannot be achieved without also understanding the governing techniques that create a rationality of the people for accepting the exercise of power by the state. Through a system of disciplination that starts in schools, the state presents its exercise of power as legitimised and rational actions that serve the interests of both individuals and societies. Through the internalisation and acceptance of the mechanisms of social order, individuals are thus moulded to serve the needs of the state.

Gramsci’s 'hegemony', Bourdieu's 'symbolic violence' and Foucault's 'governmentality' are useful theoretical tools for understanding neoliberal globalisation and the existing socio-economic, political and cultural order that provides the context in which social 
work must keep its global mission of struggling against injustices and inequalities and promoting global social justice (see also Garrett, 2018). In line with Gramsci and Foucault, Bourdieu argues that the Weberian definition of the state holding a monopoly over legitimate violence should be completed by a consideration of the notion of symbolic violence. Therefore, the state is not simply a superstructure, but an organ that fixes the limits of legitimate identities and actions by the techniques of government. Such techniques include the exercise of both physical and symbolic violence, by which individuals are forced and nurtured by the state to accept 'their place in society' (in Durkheim's terms) and to comply with the mechanisms of government. Processes of socialisation (Durkheim), disciplination (Foucault), habitualisation through symbolic violence (Bourdieu) and cultural and political hegemonisation (Gramsci) construct the individual's cognitive structures and create consent, that is, accepting the current social order as the only legitimate condition for human existence.

Although there have always been individuals and groups who deviate from and struggle against taken-for-granted capitalist and neoliberal truths, many such acts of dissent become incorporated within the current neoliberal and marketisation system. This, it is argued, is a way to marginalise and depoliticise potential opposition, which creates either conscious, active, positive consent or a passive adjustment of dissent to the system of governance (Bruff, 2010). One illustration of such a transformation is the case ofWestern Marxism, which withdrew from its traditional political scenes and instead limited itself to academic and some, marginal, political circles, largely limited to discussing questions of method and the epistemology of critical understanding (Anderson, 1998). As a result of the victory and hegemony of neoliberalism, Western Marxism reinterpreted its ethos as political practices for achieving practical outcomes. Many became engaged in acquiring the professional and social status by which to carry out practical political interventions (Shalbak, 2018).This led to some gathering around the policies of the 'Third Way' and even to cooperating with New Labour in the UK and social democracy in Nordic countries. They were drawn into a process of professionalisation, both in the academy and on the political scene, which, in line with history, created new forms of hierarchy whereby unqualified non-professionals were excluded (Perkin, 2003). It has also led to both an ignorance of Western colonialism and the existence of new immigrant groups in countries traditionally divided between labour and capital.

\section{Neoliberalisation and marketisation of higher education and research}

As many scholars of modernity and modern governance, such as Durkheim, Gramsci, Foucault and Bourdieu, have argued, modern education occupies a central role in the creation and reproduction of 'modern individuals' in capitalist societies. That is why state control over modern education is an inseparable part of modern governance. However, disciplination is not limited to the preliminary or secondary school system, but is today, and by dint of the growing popularity of higher education, also a part of the institutions of higher education. Education has also been considered to be a ground for 'development'. The leading position of the US and its Western allies in defining the discourses of development has led to the neoliberalisation of 'development' efforts, subjecting them to 'free market' competition, as per the Washington Consensus, by providing 'developing countries' with loans from the World Bank and the International 
Monetary Fund (IMF) for the implementation of structural adjustment programmes. This structural adjustment has been about enacting austerity reforms that stymie economic growth and defund public institutions, including higher education (Stein et al, 2019).There is a paradox in the idea of development, which has no solution in the neoliberal era: the development agenda aims at solving problems in the same systems that cause those problems. Therefore, as Andreotti (2006: 44) puts it, we have to ask questions such as: 'Whose story or vision for development is being privileged?'; 'In whose name?'; 'For whose benefit?'; 'By what means?'; and 'To what ends?'

The development agenda follows the idea that 'there is no alternative' beyond the neoliberal world order - as is discussed by contributors in this issue, such as Calbucura and Almonacid, Madew and Leung, and Powers, Rambare and Peeters (see also Kamali, 2015; Jönsson, 2019b). Such understanding and reforms are not only limited to the economic spheres, but also included in all aspects of late-modern social, political and cultural life around the world. In the field of higher education and research, it has created 'academic capitalism', by which universities are no longer concerned with collegiality and the defence of science and democracy, but, rather, are entrepreneurial institutions (Slaughter and Leslie, 1997; Giroux, 2007). Since 'marketisation' is the key word for understanding every aspect of human lives, students in higher education are considered as consumers and universities as producers. Universities operate under a market policy that cloaks itself under the guise of student empowerment and quality (Tomlinson et al, 2018). The quality of education is now measured by the employability of students and not the (scientific and critical) content of the education. It is the market 'out there' that is of concern and through which neoliberal politicians and 'stakeholders' force their values and needs onto higher education. The way in which schools and teaching practices are being used to maintain the status quo is turning them into mini marketplaces (Sharma, 2018). Neoliberal and neoconservative policies aim at developing human capital and labour power more suited to the interests of capital and the owners of capital: the capitalist class (Hill, 2006). This means that public education under the neoliberal order is simply one component of a larger economic system, and the focus of education policy and curriculum development, which also impacts how teachers think and teach, is organised accordingly (Hyslop-Margison and Sears, 2006).

Education in the service of neoliberalism is not only influencing higher education, but also being applied in all aspects and at all levels of education. Pre-higher education schooling, as a disciplinarian institution, is also highly influenced by neoliberal policy, legitimised by the claim of reducing inequalities and increasing school performance. This has been shown to be a 'false imaginary', which has not only failed, but also actually led to the contrary, that is, increasing segregation and inequalities (Brathwaite, 2017). This means that students arriving in higher education are already trained and prepared for the process of being professionalised and rendered employable in the neoliberal market. Neoliberalism seems to have produced a new common sense and new sets of subjectivities, which are not only imposed from above (by those exercising socio-economic and political power) and through the educational system, but also transferred to children and young people by neoliberal-minded, middle-class parents (Ball, 2010). This creates an obstacle for the radical educators of social work in their critical positioning and teaching against neoliberalism.

However, it should be said that given the fact that critiques of neoliberalism - as all-encompassing theoretical tools and logics - have been developed in the Global 
North, critiques of neoliberalism in education risk leaving aside non-economic dimensions of power and hierarchy, such as those relating to 'race' (Windle, 2019). Pedagogy and curriculum are systems that recognise and reward the outlooks, practices and values of middle-class and elite social groups, and reproduce the privileges of these groups (Bourdieu, 1966; Bourdieu and Passeron, 1990). Reproduction of such privileges in many Western countries excludes knowledge about the colonial past, slavery and current post-colonial reality, which is a situation that reproduces existing local, national and global structural and institutional discrimination and racism. Many critiques of the capitalist neoliberal system ignore the problem of racism and its role in the reproduction of inequalities. As Hall (2017) argues, the establishment of capitalism as a world order would not be possible without violent racism, slavery and colonialism (see also Williams, 1944; Loomba, 1998). As Madew and Leung (this issue) argue, many scholars in universities hide themselves behind 'neutral objectivity' as a comfortably deceptive preoccupation, and do not care about the action-oriented role of social work for promoting social justice. The individual's success is related to their obedience to power structures, organisational frames and institutional routines. Even those subjected to symbolic violence are forced to comply with the, for example, racist system in order to guarantee their success within the educational system and in the labour market (De los Reyes and Kamali, 2006; Kamali, 2009, 2015). Such a problem is also discussed in the education of social work, where the need for incorporating anti-oppressive and anti-colonial knowledge is elaborated on (Ferguson and Smith, 2012; Morley and O'Connor, 2016; Jönsson and Flem, 2018).

Social work education and research have increasingly been subjected to neoliberal and managerial measures in order for the state and the market to guarantee the reproduction of privileges for the rich and to control unprivileged groups (Ferguson and Lavalette, 2004; Ferguson, 2008; Brown, 2016; Kamali and Jönsson, 2018). The two key pillars of such policy are an emphasis on 'personal responsibility' and a particular understanding of 'community' (Ferguson, 2008). Ferguson explains that in the UK, New Labour's Third Way policy of the late 1990s and 2000s combined the neoliberal sense of 'personal responsibility', in which individuals are responsible for their own success or lack of it, with a conservative image of community. Accordingly, social work, as a profession and in terms of its education, should also be adjusted to such an understanding of society.

Critical and radical thinking has been marginalised and is under continual control by the universities' managerial and bureaucratic staff. This is a method of disciplining citizens that, as Chomsky (2014) puts it, requires reducing people's expectations for democracy, social justice and their control over the workplace. This policy places emphasis on productivity and keeping costs low, while taking power away from those who do the work and increasing the power of those in administration - which, in turn, leads to the fall of faculty and the establishment of 'all-administrative universities' (Ginsberg, 2011; Brown, 2016). The growing control of funding and education on the part of the government and market forces has brought about a destructive transformation by which the freedom of research and education has been dramatically reduced. This is what Morley and Macfarlane (2014) call the "colonisation of social work by neoliberalism' (see also Morley et al, 2017).

This takes place in line with what Foucault, in his lectures on 'the birth of biopolitics', calls 'neoliberal governmentality'. The major body of current education and research in social work (and other social science disciplines) aims at creating 
an imperialistic and colonising 'neoliberal knowledge capitalism', which imposes, to use Foucault's specific term, a dominant 'regime of truths' (Davidson-Harden, 2013). Such 'truths' are propagated, without alternatives also being offered, by powerful neoliberal states and those agents who control the global media. Most media institutions and artefacts are themselves part of a complex chain of market commodities within the wider capitalist economy (Murdock and Golding, 1973; Garnham, 1979; Herman and Chomsky, 1994; Golding and Murdock, 1997; Craig, 2004; McChesney, 2008; Mosco, 2009). The neoliberal domination of global media, such as in the case of CNN and BBC, sees the world being presented as a neoliberal world, and sees efforts to fight off any contending representations of the truth. The major body of journalism, as a discursive activity of the reconstruction of reality (Carvalho, 2008), is highly engaged in presenting the neoliberal world as normal and desirable. This also means that critical research is not given the same attention in the mainstream media as research conducted within the frame of "neoliberal knowledge capitalism' (Kamali, 2006, 2009). This is because those 'expressing opinions favoured by "the market" (i.e., the business elite) have been provided with disproportionate resources and access to influence and power through ... sponsorships in grants, access to the mass media and in influence in the political arena' (Herman, 1982: 288-9). Therefore, neoliberalism has established itself as a hegemonic ideology whose central tenets are frequently adopted by the media as default assumptions (Preston and Silke, 2011).

Critical and radical research is under constraints and its funding is increasingly reduced as a result of the domination of neoliberal ideology and the intervention of political parties and the market in social work education and research (including in defining 'desirable research' and its outcomes). If critical and radical curricula have been marginalised for a long time, they are now openly considered as 'non-scientific' and, in some cases, even dangerous and 'radicalising'. Our own experiences of the rise and fall of critical and radical social work education at Mid Sweden University provide a salient illustration. In 2011, Mid Sweden University adopted a 'Critical and Global Profile' for its education programme in social work. It created immediate resistance on the part of those professors and other academics who saw their privileges at risk of being cut. However, it became one of the most popular education programmes in the country and its critical and radical research output received international attention. Mid Sweden University - being a little university located in the far north of the country, and thus having had problems with attracting students - might reasonably be expected to be very satisfied with the educational and research success of its Department of Social Work. However, instead, 'white power' succeeded in convincing the leadership of the university that the education programme had provoked many negative reactions from 'citizens' and was propagating Marxism, Islamism (because the head of education and research at the department had a Muslim background) and radicalism. Indeed, right-wing political parties and racist neoliberal groups and individuals had even occasionally reported the Department of Social Work and thus tried to eliminate its radical profile. A notable example of this concerned one of the members of the city council, who was a politician from the neoliberal party, the Moderates. He reported the department for possessing 'communist literature' and 'forcing students to buy and read such literature', and wrote an article in the local newspaper. However, popular student support for the department and its good scientific resumé helped to keep the education programme going. In 2017, however, 
opposition within the university, supported by neoliberal, xenophobic and racist parties and groups from outside of the university, launched - with the help of the new Vice Chancellor - a challenge to the 'Critical and Global Profile' of the department and eventually, in 2019, managed to succeed in destroying it. The discriminatory actions of the university could not have been successful if the political climate in Sweden had not changed in recent years, with popular support for right-wing, racist and xenophobic parties and groups having increased dramatically since the 'refugee crisis' in 2015. The election of 2018 made a racist party, the Sweden Democrats, the third-largest party in the country. (Other researchers have also discussed such neoliberal administrative oppression in universities [see Giroux, 2007; Gutiérrez Rodríguez, 2016; Morley, 2016; Bottrell and Manathunga, 2019].)

The neoliberalisation of universities has led to the reinforcement of institutional racism and 'white supremacy' (Ahmed, 2012; Christian, 2012; Lee and Cantwell, 2012). The institutional mechanisms of racialisation and the exclusion of people of colour and of critical and radical scholars from the 'mainstream body of knowledge production' cannot be understood 'without reference to economic and political factors related to developments and changes in national, continental-wide and global capitalism' (Cole, 2009: 92). These mechanisms operate on the basis of a power matrix, the coloniality of power (Quijano, 2000), which provides easy means for integration and inclusion within mainstream society and institutions for some, and excludes and marginalises others. This takes place mainly through subtle institutional mechanisms, including an established system of exercising symbolic violence as part of the reproduction of common-sense governmentality.

As sites of knowledge production, universities are, then, strategic institutions for the reproduction of cultural hegemony (Bourdieu, 1988; Pusser and Marginson, 2013). As the institution of homo academicus, universities reflect deeply entrenched social inequalities marked by class, race, disability and migration (Gutiérrez Rodríguez, 2016). The austerity measures and policies that have been implemented in the university over recent decades signal an ideological change, which reinforces institutional racism, migration control and the rationalised division of work (Kumar, 2012). This can be viewed as a process of 're-establishing White boys-networks' within leading managerial and professional positions at universities (see Gutiérrez Rodríguez, 2016). However, it must be said that it is not only 'white boys', but also even 'white girls', who are tightening their grip over universities (and other institutions) as part of the white power structure. 'White power' reinforces its control over institutions of higher education, media, politics and other aspects of society and culture by excluding critical and radical voices, and including and bolstering those who support the power structure.

Many women and men of an immigrant or minority background are included in Western countries' social and political lives when they accept the mechanisms of the reproduction of 'white supremacy'. They gain leading positions in political institutions, as governmental officials, as vice chancellors at universities and so on - as long as they adjust themselves to the mechanisms of symbolic violence and help in reproducing 'white supremacy' within the frames of neoliberal capitalism. Moreover, their backgrounds, as immigrants or individuals from minority groups, can be used by powerful agents in order to consolidate the power structure. Given the fact that the institutions of knowledge production, that is, universities, have been significant actors in the scientification of capitalism, racism and colonialism (Eze, 1993; Bottrell and Manathunga, 2019), any struggle against global, national and local inequalities 
should include a radical restructuring of the processes of knowledge production and education.

\section{Neoliberalisation of social work practices}

The neoliberalisation of social work education has gone hand in hand with the neoliberalisation of social work practices. This is mainly because neoliberalism, in contrast to classic liberalism, involves extending market values to all human activities and social relations (Brown, 2015). The neoliberal ideological turn of placing blame for social problems on the individual has influenced almost all aspects of social work around the world over the past few decades. This has not been limited to the UK and the US, but also influenced many other countries, including the generous welfare states of Nordic countries (Kamali and Jönsson, 2018). The consequences of neoliberalism for social work practice have been addressed comprehensively in social work literature (Ferguson and Lavalette, 2006; Holscher and Sewpaul, 2006; Ferguson, 2008; Garrett, 2009; Abramovitz and Zelnick, 2016; Gray et al, 2015; Kamali and Jönsson, 2018). Neoliberalism leads the government, as the actor enabling the capitalist market to work, to prioritise capital accumulation strategies over social responsibilities towards its citizens.

Cree (2013) argues that given the fact that many social workers are employed by the state and have 'gatekeeping' or surveillance roles engaged in so-called case management services, they have little power to manage their own working lives, let alone to give power to others. These developments in social work practice can be conceptualised as a move away from the needs of clients and towards the needs of the system (Ferguson and Lavalette, 2004). Social work operates within a neoliberal capitalist system that marginalises many people and obstructs them from accessing power and influence in society. The recent decades of neoliberal capitalist globalisation and hegemony have cemented these divisions (Callinicos, 2010). In the neoliberal world view, social problems are perceived as individual problems rather than as problems created within and by socio-economic, political and cultural systems. Within the increasingly orthodox neoliberal paradigm, state intervention in social life is narrowly justified to protect the law-abiding from the dangerous 'other' (Hyslop, 2016; McKendrick and Finch, 2017). Social work practices are increasingly drowning in the state's 'frontless war on terror' in which social workers must identify 'troubled families' who are considered dangerous for the sake of 'our societies' (Kamali, 2015; McKendrick and Finch, 2017).

The neoliberal state is involved in the transfer of public assets to private hands, the deregulation of areas that were considered a public responsibility in the past, the privatisation of public services and programmes, and the launch of various market-based public policy reforms (Harvey, 2007; Peck, 2010; Schram, 2015). While the neoliberal state is withdrawing from its traditional responsibility for the provision of welfare, it is increasingly becoming an organisation for providing services to the market and for surveilling and controlling people. Utilising its control over education and the funding of social work practice, the neoliberal state is a central actor in reorganising social work education, research and practices to serve the interests of a neoliberal, discriminatory and marginalising society. The seemingly paradoxical actions of the neoliberal state - to seek to downsize government on the one hand and simultaneously work to expand its power so that it can impose the whims of the 
market on the other - are not difficult to understand. The neoliberal state is increasingly becoming a more oppressive state, which has to reinforce its policing structure. It helps the militarisation of the world and the securitisation of its domestic affairs (Kamali, 2015; Finch et al, 2019). Supporting the neoliberal global market, which creates many 'glocal' social problems, the neoliberal state has become an organ for defending the neoliberal status quo, engaging both public social work and new voluntary actors.

Education in social work is increasingly forced to equate with the educating of administrators and 'professionals' whose duty it is to adjust social work practices to the 'needs of the state' - which are, in practice, the needs of the market - instead of the needs of people. This understanding of 'professionalism' has also influenced social work practices. As Dominelli (2002: 46) argues: 'Managerially imposed procedures have repositioned professional social workers as technocrats whose capacity to exercise independent judgment is severely curtailed through bureaucratic procedures.'There is not much room for protest within the system and its legal frames. Social workers who make claims about the state's responsibility for the adverse conditions experienced by their 'clients' are confronted with a sstate that functions to defend against and deflect the social claims they raise (Crouch, 2011; Lauri, 2019).

Even social workers working in non-profit organisations are not 'free' to work beyond the imperatives and claims of neoliberalism. The market forces them to adjust themselves to the rules of neoliberal games in order to secure funding. This is mainly because the state is still the major funder of non-profit organisations (Hasenfeld and Garrow, 2012; Andersen, 2018). The dependence on government funding creates serious limitations for social workers' involvement in the policy arena. They refrain from engaging in open policy practice that challenge the state and may thus put their organisations at risk of losing essential funding (Strier and Feldman, 2018).

\section{Contributions to this issue}

The first article is written by Shane Brady, Jason Sawyer and Nathan Perkins, who critically analyse the basis of claims that the social work profession has been progressive, critical or radical. By using the perspective of critical political philosophy, the authors argue that we need to move beyond our false consciousness that social work has ever been radical and begin considering realistic ways that social work could reposition itself as a progressive profession in neoliberal times; this includes supporting the notion that radical change is driven by grass-roots, bottom-up movements of people who have made tremendous sacrifices to transform oppressive societies and systems.

Phillip Ablett and Christine Morley, using the work of the post-Marxist philosopher Cornelius Castoriadis as an analytical lens, explore social work's emancipatory potential within a radical-democratic re-visioning of revolutionary praxis. They present a theoretical justification for social work's engagement in a new collectivist-based activism that resists oppressive social forces, and they argue for revolutionary praxis beyond neoliberal policies. Then, from an anti-authoritarian perspective, Joel Izlar explores the shortcomings and risks of neoliberalised welfare austerity models that aim at increasing the welfare of marginalised groups. Contrary to its 'imagined goal', Izlar argues that in the context of welfare austerity, social welfare in communities is limited to that which can be validated through the rules of the market, a situation 
that risks reproducing disempowerment and oppression. The author suggests that we need a new, radical social work and social welfare that is anti-authoritarian and emancipatory.

Ian Cummins, in his article, explores the relevance of the theoretical legacy of Stuart Hall for radical and revolutionary social work in a time of neoliberalism and growing state violence. Cummins argues that the works of Hall, which have been crucial in the development of post-colonial, anti-racist and anti-capitalist theoretical perspectives, are highly relevant for revolutionary social work. Meanwhile, Melinda Madew and Jason Leung use post-colonialism as a theoretical frame for analysing global hunger. They argue that the genealogy of social problems, such as hunger, can be traced to a colonial history and that such problems are contemporarily reinforced by neoliberal policies. By focusing on the policies of 'food security', and providing examples from Germany and the Philippines, the authors critically analyse the underlying colonial, post-colonial and neoliberal mechanisms behind the reproduction of hunger and other social problems that occur within the frames of a seemingly neutral globalising project. They argue for an action-oriented solidarity and struggle against the global industries of food security (favouring Western countries), in alliances with peasants and other disadvantaged groups in the Global South.

Jorge Calbucura and Milton Almonacid also discuss indigenous knowledge and mobilisation by exploring social problems and resistance among the Mapuche people in Chile. They explore the historical oppression of Mapuche communities by colonial powers and the state, which has involved targeting the Mapuche's local, environmentally sustainable, culture, values and lifestyle, and forcing them to participate in (capitalist and neoliberal) 'social innovation' projects for regional development. These projects, the authors argue, are based on unsustainable Western-centric views and blueprints that reinforce post-colonial structural discrimination against the Mapuche. The authors argue for a revolutionary change in the ideas of 'development' that would resist the neoliberal structural enforcement of the mechanisms of marketisation on the Mapuche; instead, they make a plea for a radical sustainable development based on indigenous peoples' experiences and knowledge. This means a reorientation of social work action from engagement in the marketisation of the Mapuche to radical engagements against structural oppression, and instead ensuring the monitoring of the Mapuche communities' collective well-being. Meredith Powers, Komalsingh Rambare and Jef Peteers present the same critical standpoint against neoliberal capitalist development in their critical analysis of 'degrowth' as an alternative to the devastating process of unlimited 'growth', a process that leads to increasing social inequalities and ecological injustices. Based on a case study in Mauritius, the authors demonstrate the possibility of degrowth as a radical transformative alternative that can help in counteracting neoliberal destructive forces and in fostering sustainable involvements. They make a plea for social workers' radical engagement in such struggles and processes.

This special issue also offers a look at some radical pioneers in social work. Here, Allucia Lulu Shokane and Mogomme Masoga offer a tribute to the first black social work women in South Africa. The authors cover the roles of their political struggles against the violent structures and processes of apartheid and their activism for social justice. Meanwhile, in the part entitled 'Voices from the Frontline', Shirley Worland, based on her own experiences of being part of research and educational programmes in the Karenni refugee camps on the Thai-Myanmar border, explores the radical and 
emancipatory educational programmes and practices that help to radically improve the lives of 'the damnés' (or the wretched of the earth, in the notorious words of Fanon).

This issue includes book reviews of: Iain Ferguson,Vasilios loakimidis and Michael Lavalette's Global social work in a political context: Radical perspectives; Quinn Slobodian's Globalists:The end of empire and the birth of neoliberalism; and Masoud Kamali and Jessica H.Jönsson's Neoliberalism, Nordic welfare states and social work: Current and future challenges.

\section{Conclusions: a social work revolution against symbolic violence and governmentalisation}

Contributors to this special issue highlight multiple problems related to social work practices within the neoliberal world order and provide argumentation for and illustrations of alternative radical actions. They are, in different ways, questioning the arbitrary post-colonial and neoliberal 'Western truths' - such as unlimited growth, capitalist notions of development, the global market, downsized states and the emphasis on 'individual responsibility' - which continue to influence the theories, education and practices of social work all around the world. As Marx argued, one should never judge any era's ideology by its own terms, which is an insight that applies particularly to the era of neoliberalism (Preston and Silke, 2011). The process of governmentalisation and the mechanisms of symbolic violence, which have been an inseparable part of Western modernisation projects, have consolidated capitalism, marketisation and neoliberalism as the only alternatives. Neoliberal states, that is, the majority of the states in the world, are the political organisations of neoliberal policies, which help in securing the functions of the 'free capitalist market'. Although neoliberal ideology rhetorically proposes a downsized, non-interventionist and 'thin' state that does not hamper progress and economic freedom (Strier and Feldman, 2018), it creates a dual state: a thin and a strong state simultaneously. The neoliberal state is thin and weak when it comes to the welfare of people, but strong when it comes to the protection of the neoliberal market. In this connection, the neoliberal state is also called the 'securitising state' (Kamali, 2015). Neoliberalism calls for the restructuring of the state by blurring the boundaries between the state, the market and civil society (Harvey, 2007; Wacquant, 2012). The neoliberal state is necessary to promote a competitive market order within both state and non-state institutions (Garrett, 2009).

The neoliberal state, like the Lernaean Hydra in Greek mythology, is multi-headed, playing multiple active roles in social life (Schram, 2015). Social work research, education and practices are therefore subjected to strong and encompassing state policies and pressures to be adjusted to the neoliberal market. It often strongly dictates policies; at other times, it passively observes the competition among social claims; and sometimes it mediates the claims raised by different actors (Davies, 2014). This mediation takes place both directly, through state policies and changing legal frames, and indirectly, through control over public education and its institutions. This means that the state uses many techniques, such as the educational system and mass media, to make people internalise the neoliberal social order and the notion that market fundamentalism is the only alternative. In other words, people reproduce their own subordination through the gradual internalisation and acceptance of those structures that subordinate them. Such subordination often takes place without the direct use of physical violence. The strong neoliberal state punishes deviances from, and rewards compliance to, neoliberal policies and 'truths'. However, for the defeat of this modern 
neoliberal Lernaean Hydra, it is not a powerful hero, a Hercules, that is needed, but, rather, global and collective revolutionary actions in and across many spheres.

One of the most important forms of revolutionary action is to disturb the reproduction of the legitimisation of neoliberalism. The educational institutions, such as schools and universities, are producing the 'acceptance' of and subordination to the neoliberal world order, a world order that is increasingly militarised. As Giroux (2007) argues, post-9/11 securitisation policies have created a military-industrial complex in which the lines between military and civilian functions have been eroded, resulting in the paramilitarisation of civil society, including within the most powerful setting where the minds of generations are shaped, namely, higher education institutions. The militarisation of knowledge production is legitimised by the need for security in a time of permanent 'war on terror' (Kamali, 2015). Through controlling the research funds, education and public practices of social work, the neoliberal state is increasingly forcing social work academics to adjust themselves to the strong state. Therefore, we are presently in a situation where there appears to be a conspicuous lack of alternatives (Macartney, 2009: 116-17). The fact that progressive and leftist political parties and trade unions are heavily compromised by their association with neoliberalism (Bruff, 2010) makes the situation for progressive social work academics worse. As discussed earlier, the academic-industrial complex creates academic repression and encourages neoliberal education (Nocella and Juergensmeyer, 2017). Committed academics should use their privileges in the manner of 'undoing privilege' (see Pease, 2010) to delegitimise neoliberalism in a number of ways: by fighting neoliberal management in universities; by fighting against neoliberal curricula and manners in the education of social work; by fighting for the rights of 'collegium' and for the elimination of the influence of neoliberal administration over the content of the education of social work; by participating in active debate against neoliberal ideology and social policy; by using their privileged positions and influence to foster radical revolutionary thinking within and outside of universities; and by establishing global organs for supporting academic freedom and those radical academics who are increasingly subjected to academic oppression.

Without greater emphasis on professional practices targeting radical changes within the institutions and profession of social work, the production of academic knowledge alone risks creating isolated academic circles that are satisfied with counting the numbers of publications, and with contributing to the neoliberal academic-industrial complex and reproducing what is essentially academic 'tittytainment'. To be radical means to work for large-scale changes to societal institutions and the disruption of oppressive narratives, the dominant culture and discourses that marginalise people (Thomas et al, 2011; Brady et al, 2014; Brady and Moxley, 2016). As Brady et al argue in this volume, we have to admit that the history of social work has shown that it has been an active part of larger-level institutions of social control, whether these are institutions of faith, governments or corporations (Hasenfeld and Garrow, 2012; Mullaly and Dupré, 2018), and that there is little evidence confirming that the social work profession ever substantially focused on transforming societal systems, on challenging the status quo culture or on dismantling dominant narratives. Therefore, social work needs a revolutionary agenda. The social work profession needs a global reorganisation, with the incorporation of, and adaptation to, radical and revolutionary knowledge, positioning and action. Those participating in and at the head of such organisations and institutions 
must take a critical and reflexive position and promote revolutionary actions. The self-reflexivity of such organisations is necessary, leading to the re-evaluation of the ideological basis of their national, international and global activities, including the very existence of conferences, symposiums, documents and ethical principles guiding such organisations and activities.

The following are some suggestions for revolutionary changes that should take place within the discipline of social work in order to resist neoliberalism, racism, neo-colonialism and imperialism, and to counteract the destructive role of the strong state that, in cooperation with global capitalist companies and military industries, is destroying our globe and human societies:

- Decolonisation of knowledge. As contributors to this special issue and many other critical and radical researchers have argued, the Western-centric knowledge base of social work research and education is part of the problem facing a radical and revolutionary social work aimed at monitoring equality, justice and better life chances for everybody, irrespective of their place of birth, nationality, skin colour, class, ethnicity, gender, religion and other difference-making categorisations. This means academic struggle against the reproduction of the coloniality of knowledge production and education, and a commitment to radical change in the curriculum of social work education.

- Revolutionary resistance to and struggle against governmentalisation. Social work academics and practitioners should resist and denounce any activity that reproduces governmentalisation, that is, any activity that helps in the reproduction of 'false consciousness' about the real and structural roots of global inequalities and social problems. One suggestion is to establish a 'solidary fund' by using the history of the Swedish labour movement's struggle for equality. In 1971, the Swedish Confederation of Trade Unions (LO) suggested the establishment of 'employee funds' by which to counteract the capitalist market's uncontrolled functions, which had seen employees being harmed. Such funds were established in 1975 and in an interview with the official journal of LO, Fackföreningsrörelsen [The Unions], the LO economist Rudolf Meidner (1975: 11) said: "We would like to deprive the old capital owners their power, which they exercise because of their ownership. All experiences show that influence and control [over capital] are not enough. Ownership plays a decisive role. I want to refer to Marx and Wigforss: We can basically not change the society, without changing ownership.' Although such a radical idea as 'employee funds' was subsequently 'modified' and deradicalised by the Social Democratic Party in Sweden, and eliminated by the victorious neoliberal government in 1991, it does serve as a model for creating alternatives to the capitalist system of ownership. The fact is that the neoliberal ownership of universities and research funds is increasingly eroding radical approaches to research and education, replacing them with approaches that are influenced and informed by a deeply vested interest in maintaining the status quo. This makes necessary the establishment of alternative systems of funding, as well as action against such a deterioration of critical knowledge production, knowledge that would help create a better world for everybody. We should be precisely using our privileges as researchers, educators and practitioners of social work towards the end goal of 'undoing privileges' (Pease, 2010) by creating the necessary organisation, associations and funds for supporting radical research and education, 
and promoting revolutionary practices and changes. As Bob Pease argues, privilege is the other side of oppression that has been given insufficient attention in both critical theories and in the practices of social change. That is why privileged and dominant groups have been allowed to reinforce their privileges and power. We suggest the establishment of an international fund (or funds) for supporting radical and revolutionary research and transformations. This solidary fund (or funds) can be commonly organised by international organisations of social work, such as the International Federation of Social Workers (IFSW), International Association of Schools of Social Work (IASSW), International Council on Social Welfare (ICSW) and their local, national, regional and international partners, and could be financed through the following actions:

a. Redistribution of conference costs. As privileged academicians, we are spending millions on expensive national and international conferences that can be reduced in cost by organising for them to be held digitally - something that will make them more open for everybody, including those unprivileged groups and countries that are normally excluded from such conferences. The conference fees could be transferred to such a fund.

b. Membership fees. Part of the membership fees that are paid to international social work organisations by educational institutions, organisations and members could be transferred to the fund.

c. Creating a 'solidary certificate'. A certificate could be provided to research and educational institutions, as well as to social work organisations, which are committed to global solidary and sustainable actions as a major social work ethical commitment that requires 'undoing privileges'. Such a certificate could be obtained by paying a fee, either directly to the fund or to international social work organisations that will transfer the fees to the fund.

These are just a few examples of financing the 'solidary fund', and these could be developed by the international cooperation and engagement of many committed researchers, educators and practitioners, such as those engaged in Social Work Action Network (SWAN). The fact is that we can no longer be dependent on governmental funds for conducting radical and revolutionary research, and promoting revolutionary and necessary changes in a world that is more divided than ever before.

- Revolutionary resistance to and struggle against symbolic violence. The capitalist and neoliberal control of education and of national and global media provides the neoliberal state and powerful agents with the means to legitimate oppression, colonial knowledge, racism and the globalisation of neoliberalism by presenting inequalities as the consequences of 'individual choices' and neoliberal capitalism as 'the only alternative'. This requires the active participation of social work academics and practitioners in public debates and in generating new 'revolutionary discourses' and practices that challenge oppressive categorisations and discourses in politics and the media.

- Revolutionary resistance to and struggle against the surveillance state. Neoliberal states' securitisation policies have influenced the role of social work and social workers by engaging them in surveillance policies and actions. This requires a revolutionary and reflexive positioning of social workers in their everyday practices by establishing lasting relations with progressive activist groups in civil 
society. This may even require some seemingly 'illegal actions', such as helping and organising undocumented migrants and other excluded groups to gain political and social rights - actions deemed undesirable by neoliberal governments.

- Promoting activism in social work. Social work is a profession defending human dignity and the value of all human beings, irrespective of their place of birth, status, skin colour, gender, ethnicity and other differentiating categorisations. This means that social work is a profession of activism and anti-racism that must participate in local, national and global social movements, such as indigenous and peasants' movements (discussed in this issue), for liberation from all forms of oppression.

These suggested radical and revolutionary actions require the engagement of international and global actors of social work. Such organisations should make a commitment to these revolutionary changes - much needed in the current neoliberal world order - and act accordingly. It must be considered that many members of such organisations have been educated in and are part of the reproduction of neoliberal and colonial knowledge in a post-colonial world, where the reproduction of global privileges is legitimised through a symbolic violence that forces many to adjust themselves to neoliberal ideology and policies. The global ethics of social work should be revised and include a revolutionary change in the goals of global social work, which should be working towards global equality. This means that such organisations should encourage its members towards activism and revolutionary action, and make systematic evaluations of such actions.

We are aware that such changes may evoke opposition, not only from leading members of such organisations, but also from powerful national and international organs and agents, including neoliberal states and their neoliberalised welfare organisations and supporters. However, the fact that the neoliberalisation, militarisation and marketisation of the world are destroying any structural and institutional possibilities for the existence of a peaceful and sustainable world, with equal life chances for all human beings, forces us to leave behind many taken-for-granted discourses and habitual patterns of action. Social work and social workers must be active agents of radical and revolutionary structural and institutional changes, targeting global inequalities and oppressions, and helping to create a better world for all human beings. Otherwise, we risk being 'unwilling contributors' to the processes that reproduce global structural inequalities and oppressions.

\section{Guest editors}

Masoud Kamali and Jessica H. Jönsson.

\section{Conflict of interest}

The authors declare that there is no conflict of interest.

\section{References}

Abramovitz, M. and Zelnick,J. (2016) Privatization in the human services: impact on the front lines and the ground floor, In M. Fineman, U. Andersson and M. Mattsson (eds), Privatization, vulnerability, and social responsibility, London: Routledge, pp. 182-200.

Ahmed, S. (2012) On being included, Durham: Duke University Press.

Anderson, P. (1998) The origins of postmodernity, London:Verso. 
Andersen, L.L. (2018) Neoliberal drivers in hybrid civil society organisations: Critical readings of civicness and social entrepreneurism. In M. Kamali and J. H. Jönsson (eds), Neoliberalism, Nordic welfare states and social work: Current and future challenges, London: Routledge, pp. 25-34.

Andreotti,V. (2006) Soft versus critical global citizenship education, Policy \& Practice: A Development Education Review, 3, 40-51.

Baer, A.H. (2012) Global capitalism and climate change: The need for an alternative world system, Lanham, MA: AltaMira Press.

Ball, S. (2010) Is there a global middle class? The beginnings of a cosmopolitan sociology of education: a review, Journal of Comparative Education, 69(1): 137-61.

Bassett, L. (2008) Can conditional cash transfer programs play a greater role in reducing child undernutrition?, SP Discussion Paper No. 0835, Washington, DC: World Bank.

Bottrell, D. and Manathunga, C. (eds) (2019) Resisting neoliberalism in higher education volume I: Seeing through the cracks, London: Palgrave Macmillan.

Bourdieu, P. (1966) L'école conservatrice: les inégalités devant l'école et devant la culture [Conservative schooling: inequalities in school and culture], Revue Française de Sociologie, 7(3): 325-47.

Bourdieu, P. (1988) Social space and symbolic power, Sociological Theory, 7: 18-26.

Bourdieu, P. and Passeron, J.C. (1990) Reproduction in education, society, and culture, Newbury Park, CA: Sage.

Brady, S.R. and Moxley, D. (2016) Plurality and fragmentation in social work: analyzing the implications of Flexner using a philosophy of science perspective, Journal of Social Work Education, 52(1): 74-88. doi: 10.1080/10437797.2016.1174639

Brady, S.R., Schoeneman, A.C. and Sawyer, J.M. (2014) New directions in critical community practice: assessing and analyzing the damaging impact of neo-liberalism on community practice, Journal for Social Action in Counseling and Psychology, 6(1): 36-60.

Brathwaite, J. (2017) Neoliberal education reform and the perpetuation of inequality, Critical Sociology, 43(3): 429-48. doi: 10.1177/0896920516649418

Brown, C. (2016) The constraints of neo-liberal new managerialism in social work education, Canadian Social Work Review, 33(1): 115-23. doi: 10.7202/1037094ar

Brown, W. (2015) Undoing the demos: neoliberalism's stealth revolution, New York, NY: Zone Books.

Bruff, I. (2010) Germany's Agenda 2010 reforms: passive revolution at the crossroads, Capital \& Class, 34(3): 409-28. doi: 10.1177/0309816810378153

Callinicos, A. (2010) Bonfire of illusions: The twin crises of the liberal world, Malden, MA: Polity Press.

Carvalho, A. (2008) Media(ted) discourse, Journalism Studies, 9(2): 161-77. doi: 10.1080/14616700701848162

Chomsky, N. (2014) How America's great university system is being destroyed, Public lecture via Skype to Adjunct Faculty Association of the United Steelworkers, 4 February, Pittsburgh, PA, https://www.alternet.org/2014/02/ chomsky-how-americas-great-university-system-getting/

Christian, M. (ed) (2012) Integrated but unequal: Black faculty in predominantly white spaces, Trenton, NJ: Africa World Press.

Cole, M. (2009) The color-line and the class struggle: a Marxist response to critical race theory in education as it arrives in the United Kingdom, Power and Education, 1(1): 111-24. doi: 10.2304/power.2009.1.1.111 
Craig, R.L. (2004) Business, advertising, and the social control of news, Journal of Communication Inquiry, 28(3): 233-52. doi: 10.1177/0196859904264686

Cree,V. (2013) New practices of empowerment, In M. Grey and S.A. Webb (eds), The new politics of social work, Basingstoke: Palgrave Macmillan, pp. 145-58.

Crouch, C. (2011) The strange non-death of neoliberalism, Cambridge: Polity Press. Davidson-Harden,A. (2013) What is social sciences and humanities research 'worth'? Neoliberalism and the framing of social sciences and humanities work in Canada, Policy Futures in Education, 11(4): 387-400. doi: 10.2304/pfie.2013.11.4.387

Davies, W. (2014) The limits of neoliberalism: Authority, sovereignty, and the logic of competition, London: Sage.

De los Reyes, P and Kamali, M. (2006) Bortom Vi och Dom: Teoretiska reflektioner om makt, integration och strukturell diskriminering [Beyond Us and Them:Theoretical reflections on power, integration and structural discrimination], Stockholm: Fritzes.

Dominelli, L. (2002) Feminist social work theory and practice, Basingstoke: Palgrave.

Eze, E.C. (ed) (1993) Race and the Enlightenment: A reader, Blackwell: Cambridge.

Ferguson, I. (2008) Reclaiming social work: Challenging neo-liberalism and promoting social Justice, London: Sage.

Ferguson, I. and Lavalette, M. (2004) Beyond power discourse: alienation and social work, British Journal of Social Work, 34(3): 297-312.

Ferguson,I.and Lavalette,M.(2006) Globalization and global justice:towards a social work of resistance, International Social Work, 49:309-18. doi:10.1177/0020872806063401

Ferguson, I. and Smith, L. (2012) Education for change: student placements in campaigning organisations and social movements in South Africa, British Journal of Social Work, 42(5): 974-94. doi: 10.1093/bjsw/bcr143

Ferguson, I., Ioakimidis, V. and Lavalette, M. (2018) Global social work in a political context: Radical perspectives, Bristol: Policy Press.

Finch, J., Jönsson, J.H., Kamali, M. and McKendrick, D. (2019) Social work and countering violent extremism in Sweden and the UK, European Journal of Social Work, doi: 10.1080/13691457.2019.1657803.

Foucault, M. (2003) Society must be defended: Lectures at the College de France, 1975-76, New York, NY: Picador.

Foucault, M. (2007) Security, territory, population: Lectures at the College de France, 1977-78, Basingstoke: Palgrave MacMillan.

Fukuyama, F. (1992) The end of history and the last man, New York, NY: Avon Book.

Garnham, N. (1979) Contributions to a political economy of mass communication, Media, Culture \& Society, 1(2): 122-46.

Garrett, P.M. (2008) Thinking with the Sardinian:Antonio Gramsci and social work, European Journal of Social Work, 11(3): 237-50. doi: 10.1080/13691450802075592

Garrett, P.M. (2009) 'Transforming' children's services? Social work, neoliberalism and the 'modern' world, Maidenhead: Open University Press.

Garrett, P.M. (2018) Social work and social theory: Making connections (2nd edn), Bristol: Policy Press.

Ginsberg, B. (2011) The fall of the faculty: The rise of the all-administrative university and why it matters, New York, NY: Oxford University Press.

Giroux, H.A. (2007) The University in chain: Confronting the military-industrial-academic complex, Boulder, CO: Paradigm Publishers.

Golding, P. and Murdock, G. (1997) The political economy of the media, Cheltenham: Edward Elgar. 
Gramsci, A. (1971) Selections from the prison notebooks (trans and ed Q. Hoare and G.N. Smith), New York, NY: International Publishers.

Gray, M., Mitchell, D., Agllias, K., Howard,A. and Schubert, L. (2015) Perspectives on neoliberalism for human service professionals, Social Service Review, 89(2): 368-92. doi: $10.1086 / 681644$

Grossberg, L. (1996) History, politics and postmodernism: Stuart Hall and cultural studies, In D. Morley and K.-H. Chen (eds), Stuart Hall: Critical dialogues in cultural studies, London: Routledge.

Gutiérrez Rodríguez, E. (2016) Sensing dispossession: women and gender studies between institutional racism and migration control policies in the neoliberal university, Women's Studies International Forum, 54: 167-77.

Hall, S. (2017) Selected political writings, Durham: Duke University Press.

Harvey, D. (2007) A brief history of neoliberalism, Oxford: Oxford University Press.

Hasenfeld,Y. and Garrow, E.E. (2012) Nonprofit human-service organizations, social rights, and advocacy in a neoliberal welfare state, Social Service Review, 86(2):295-322. doi: $10.1086 / 666391$

Herman, E. (1982) The institutionalization of bias in economics, Media, Culture $\mathcal{E}$ Society, 4(3): 275-91. doi: 10.1177/016344378200400307

Herman, E. and Chomsky, N. (1994) Manufacturing consent: The political economy of the mass media, London:Vintage.

Hill, D. (2006) Class, neoliberal global capital, education and resistance, Social Change, 36(3): 47-76. doi: 10.1177/004908570603600302

Hobsbawm, E. (1977) Gramsci and political theory, Marxism Today, 205-13.

Holscher, D. and Sewpaul,V. (2006) Ethics as a site of resistance: the tension between social control and critical reflection, Research Reports, 1: 251-72.

Hyslop, I.K. (2016) Social work in the teeth of a gale: a resilient counter-discourse in neoliberal times, Critical and Radical Social Work, 4(1): 21-37. doi: 10.1332/204 986016X14519919041316

Hyslop-Margison, E.J. and Sears, A.M. (2006) Neo-liberalism, globalization and human capital learning: Reclaiming, Dordrecht: Springer Netherlands.

Jönsson, J.H. (2019a) Servants of a 'sinking Titanic' or actors of change? Contested identities of social workers in Sweden, European Journal of Social Work, 22(2):212-24.

Jönsson, J.H. (2019b) Overfishing, social problems and ecosocial sustainability in Senegalese fishing communities, Journal of Community Practice, doi: 10.1080/10705422.2019.1660290.

Jönsson,J.H. and Flem,A.L. (2018) International field training in social work education: beyond colonial divides, Social Work Education, 37(7): 895-908.

Kamali, M. (2006) Multiple modernities, civil society and Islam:The case of Iran and Turkey, Liverpool: Liverpool University Press.

Kamali, M. (2009) Racial discrimination: Institutional patterns and politics, New York, NY: Routledge.

Kamali,M.(2012) Multiple modernities and mass communications in Muslim countries, Global Media and Communication, 8(3): 243-68. doi: 10.1177/1742766512459121

Kamali, M. (2015) War, violence and social justice: Theories for social work, London: Routledge.

Kamali, M. and Jönsson, J.H. (eds) (2018) Neoliberalism, Nordic welfare states and social work: Current and future challenges, London: Routledge. 
Kumar, R. (2012) Education and the reproduction of capital: Neoliberal knowledge and counterstrategies, New York, NY: Palgrave Macmillan.

Lauri, M. (2019) Mind our own business: technologies for governing social worker subjects, European Journal of Social Work, 22(2): 338-349. doi: 10.1080/13691457.2018.1529661

Lee, J. J. and Cantwell, B. (2012) The global sorting machine. An examination of racism among international students and postdoctoral researchers. In B. Pusser (ed), Universities and the public sphere. Knowledge creation and state building in the era of globalization, New York, NY: Routledge, pp. 47-64.

Luxemburg, R. (2003) The accumulation of capital, London: Routledge.

Loomba, A. (1998) Colonialism/postcolonialism, London: Routledge.

Macartney, H. (2009) Disagreeing to agree: financial crisis management within the 'logic of no alternative', Politics, 29(2): 111-20. doi: 10.1111/j.1467-9256.2009.01346.x

McChesney, R.W. (2008) The political economy of media: Enduring issues, emerging dilemmas, New York, NY: Monthly Review Press.

McKendrick, D. and Finch, J. (2017) Downpressor man: securitisation, safeguarding and social work, Critical and Radical Social Work, 5(3): 287-300. doi: 10.1332/2049 86017X15029697482460

Meidner, R. (1975) Fackföreningsrörelsen: Organ för Landsorganisationen i Sverige, Official Journal of the Swedish Confederation of Trade Unions, No. 19, Stockholm: Landssekretariatet.

Morley, C. (2016) Promoting activism through critical social work education: the impact of global capitalism and neoliberalism on social work and social work education, Critical and Radical Social Work, 4(1):39-57. doi: 10.1332/204986016X 14519919041398

Morley, C. and MacFarlane, S. (2014) Critical social work as ethical social work: using critical reflection to research students' resistance to neoliberalism, Critical and Radical Social Work, 2(3): 337-55. doi: 10.1332/204986014X14096553281895

Morley, C., MacFarlane, S. and Ablett, P. (2017) The neoliberal colonisation of social work education: a critical analysis and practices for resistance, Advances in Social Work and Welfare Education, 19(2): 25-40.

Morley, C. and O'Connor, D. (2016) Contesting field education in social work: Using critical reflection to enhance student learning for critical practice. In I. Taylor, $\mathrm{M}$, Bogo, M. Lefevre and B. Teater (eds), Routledge international handbook of social work education, New York, NY : Routledge, pp. 220-231.

Morton, A.D. (2007) Unravelling Gramsci: Hegemony and passive revolution in the global political economy, London: Pluto.

Mosco,V. (2009) The political economy of communication, Los Angeles, CA: Sage.

Motta, S.C. and Bailey, D.J. (2007) Neither pragmatic adaptation nor misguided accommodation: modernisation as domination in the Chilean and British Lefts. Capital \& Class, 92: 107-38. doi: 10.1177/030981680709200105

Mullaly, B. and Dupré, M. (2018) The new structural social work: Ideology, theory, and practice, New York, NY: Oxford University Press.

Murdock, G. and Golding, P. (1973) For a political economy of mass communications, In R. Miliband and J. Saville (eds), The socialist register, London: Merlin Press, pp. 205-34. 
Nocella,A.J. and Juergensmeyer, E. (eds) (2017) Fighting academic repression and neoliberal education: Resistance, reclaiming, organizing, and Black Lives Matter in education, Berlin: Peter Lang.

Pease, B. (2010) Undoing privileges: Unearned advantage in a divided world, London: Zed Books.

Peck, J. (2010) Constructions of neoliberal reason, Oxford: Oxford University Press.

Perkin, H. (2003) The rise of professional society: England since 1880, London: Routledge.

Preston, P. and Silke, H. (2011) Market 'realities': de-coding neoliberal ideology and media discourses, Australian Journal of Communication, 38(3): 47-64.

Pusser, B. and Marginson, S. (2013) University rankings in critical perspective, The Journal of Higher Education, 84(4): 544-68. doi: 10.1353/jhe.2013.0022

Quijano, A. (2000) Coloniality of power and Eurocentrism in Latin America, International Sociology, 15(2): 215-32. doi: 10.1177/0268580900015002005

Sassoon, A.S. (1987) Gramsci's politics, London: Hutchinson Education.

Schram, S.F. (2015) The return of ordinary capitalism: Neoliberalism, precarity, Occupy, New York, NY: Oxford University Press.

Schwartz, M. (2011) Military neoliberalism: endless war and humanitarian crisis in the twenty-first century, Societies Without Borders, 6(3): 190-303.

Shalback, I. (2018) Hegemony thinking: a detour through Gramsci, Thesis Eleven, 147(1): 45-61. doi: 10.1177/0725513618787660

Sharma, M. (2018) Seeping deficit thinking assumptions maintain the neoliberal education agenda: exploring three conceptual frameworks of deficit thinking in inner-city schools, Education and Urban Society, 50(2): 136-54. doi: $10.1177 / 0013124516682301$

Short, N. (2007) The international politics of post-conflict reconstruction in Guatemala, New York, NY: Palgrave Macmillan.

Slaughter, S. and Leslie, L.L. (1997) Academic capitalism: Politics, policies, and the entrepreneurial university, Baltimore, MD: Johns Hopkins University Press.

Stein, S., De Oliveira Andreottia,V. and Sušab, R. (2019) 'Beyond 2015', within the modern/colonial global imaginary? Global development and higher education, Critical Studies in Education, 60(3): 281-301. doi: 10.1080/17508487.2016.1247737

Strier, R. and Feldman, G. (2018) Reengineering social work's political passion: policy practice and neo-liberalism, The British Journal of Social Work, 48(3): 751-68. doi: 10.1093/bjsw/bcx064

Thomas, M.L., O'Connor, M. and Netting, F.E. (2011) A framework for teaching community practice, Journal of Social Work Education, 47(2): 337-55. doi: 10.5175/ JSWE.2011.200900081

Tomlinson, M., Enders, J. and Naidoo, R. (2018) The Teaching Excellence Framework: symbolic violence and the measured market in higher education, Critical Studies in Education, 12(12): 1-16. doi: 10.1080/17508487.2018.1553793

Wacquant, L. (2012) Crafting the neoliberal state: workfare, prisonfare and social insecurity, Sociological Forum, 25(2): 197-220. doi:10.1111/j.1573-7861.2010.01173.x

Williams, E. (1944) Capitalism E slavery, London: University of North Carolina Press.

Windle, J. (2019) Neoliberalism, imperialism and conservatism: tangled logics of educational inequality in the Global South, Discourse: Studies in the Cultural Politics of Education, 40(2): 191-202. doi: 10.1080/01596306.2019.1569878 